\title{
New molecular complex of ammonium glycyrrhizate with rutin
}

\author{
L.A. Yakovishin ${ }^{a^{*}}$ (D), V.D. Ratnikov ${ }^{\text {a }}$ (D), P.I. Bazhan ${ }^{a}$, G.P. Zaitsev ${ }^{b}$ (D) \\ a: Sevastopol State University, 299053 University st., 33, Sevastopol, Russia \\ b: All-Russian National Research Institute of Viticulture and Winemaking "Magarach" of RAS, \\ 298600 Kirova st., 31, Yalta, Russia \\ * Corresponding author: chemsevntu@rambler.ru
}

This short communication (letter) belongs to the MOSM2021 Special Issue.

(C) 2021, The Authors. This article is published in open access form under the terms and conditions of the Creative Commons Attribution (CC BY) license (http://creativecommons.org/licenses/by/4.o/).

\begin{abstract}
A new 1:1 molecular complex of triterpene glycoside ammonium glycyrrhizate (GC) with flavonoid glycoside rutin (Rut) was obtained in aqueous ethanol. The stability constant $(9.7 \pm 0.2) \cdot 10^{4}(\mathrm{~mol} / \mathrm{L})^{-1}$ was calculated for the complex via isomolar curves. The complexation was studied by UV- and ATR IR-Fourier spectroscopy and a method of isomolar series. The hydrogen bonds and hydrophobic interactions are formed in the molecular complex. A preliminary antioxidant activity assessment of the complex was made.
\end{abstract}

\section{Keywords}

triterpene glycosides ammonium glycyrrhizate rutin molecular complex antioxidant capacity

Received:03.11.2021

Revised: 21.12.2021

Accepted: 21.12.2021

Available online: 11.01 .2022

\section{Introduction}

Rutin (Rut; Fig. 1) is one of the most famous flavonols and glycosides [1]. Its aglycone is quercetin. Found in different plants, Rut has P-vitamin activity and exhibits antimicrobial, antioxidant, anti-inflammatory, antidiabetic, antispasmodic, antisclerotic, diuretic, and anticancer effects [1]. Rut has a low solubility in water and limited membrane permeability [1]. The therapeutic effect of Rut is limited due to its bioavailability [1]. The study [2] showed that the solubility and bioavailability of bioactive compounds can be significantly increased by their molecular complexation with triterpene glycosides. Triterpene saponins are amphiphilic multidentate ligands that are capable of molecular complexation with both polar and non-polar fragments of other molecules [2].

Glycyrrhizic acid (GA) and its monoammonium salt (ammonium glycyrrhizate, glycyram, GC; Fig. 1) are widely used as complexing agents [2-6]. GA is the main triterpene saponin of licorice roots [2]. GA increases permeability of cell membranes [5]. Previously, we studied the molecular complex of quercetin with GC [6]. However, molecular complexes of Rut with GC have not been described. This article reports the preparation of a new molecular complex of GC with Rut.

\section{Experimental}

GC (purity $\geq 95 \%$ by high-performance liquid chromatography (HPLC)) was purchased from Calbiochem. Other chemicals of the highest grade of purity were obtained from Sigma-Aldrich.
The isomolar series were prepared by mixing $10^{-}$ $4 \mathrm{~mol} / \mathrm{L}$ solutions of $\mathrm{GC}$ and Rut in $70 \%$ aqueous ethanol (v/v) with continuous stirring at $25^{\circ} \mathrm{C}$ for $40 \mathrm{~min}$. Spectroscopic analysis of isomolar series was performed on a LEKI SS2110UV spectrophotometer using a quartz cuvette $(l=1 \mathrm{~cm})$ at $25^{\circ} \mathrm{C}$. Stability constant of the complex was calculated according to the A.K. Babko method based on the isomolar curves $[5,7]$.

The complex of Rut with GC was preparatively obtained by the liquid-phase method. For this purpose, $1 \mathrm{mmol}$ of the substances was mixed with $50 \mathrm{~mL}$ of $70 \%$ aqueous ethanol $(\mathrm{v} / \mathrm{v})$. The obtained mixture was incubated with continuous stirring at $50{ }^{\circ} \mathrm{C}$ for $1.5 \mathrm{~h}$. The organic solvent was removed by vacuuming. The synthesized complex was analyzed by IR spectroscopy. The IR spectra were recorded on a Simex FT801 IR-Fourier spectrometer (Russia) in the $4000-550 \mathrm{~cm}^{-1}$ region (spectral resolution $4 \mathrm{~cm}^{-1} ; 25$ scans) using the ATR accessory with a diamante crystal plate.

IR spectrum of Rut $\left(\mathrm{v}, \mathrm{cm}^{-1}\right): 3415(\mathrm{OH}), 3343(\mathrm{OH})$, $2954(\mathrm{CH}), 2914(\mathrm{CH}), 2847(\mathrm{CH}), 1656(\mathrm{C}=\mathrm{O}), 1596\left(\mathrm{C}=\mathrm{C}_{\mathrm{Ar}}\right)$, $1572\left(\mathrm{C}=\mathrm{C}_{\mathrm{Ar}}\right), 1552\left(\mathrm{C}=\mathrm{C}_{\mathrm{Ar}}\right), 15 \mathrm{O} 2\left(\mathrm{C}=\mathrm{C}_{\mathrm{Ar}}\right), 1453\left(\mathrm{C}=\mathrm{C}_{\mathrm{Ar}}, \mathrm{CH}\right)$, $1426(\mathrm{CH}), 1405(\mathrm{C}-\mathrm{OH}), 1360(\mathrm{C}-\mathrm{OH}, \mathrm{CH}), 1313(\mathrm{CH})$, 1294 (C-O-C, C-OH), 1234 (C-O-C, C-OH), 1203 (C-O-C, $\mathrm{C}-\mathrm{OH}), 1168$ (C-O-C, C-OH), 1149 (C-O-C, C-OH), 1123 (C-O-C, $\mathrm{C}-\mathrm{OH}), 1093$ (C-O-C, C-OH), 1059 (C-O-C, C-OH), 1041 (C-O-C, $\mathrm{C}-\mathrm{OH}), 1013$ (C-O-C, C-OH), 999 (C-O-C, C-OH), $967(\mathrm{CH})$, $943(\mathrm{CH}), 910$ (monosaccharide ring), $880(\mathrm{CH}), 848(\mathrm{CH})$, $826(\mathrm{CH}), 807(\mathrm{CH}), 794(\mathrm{CH}), 727(\mathrm{CH}), 719(\mathrm{CH}), 707(\mathrm{CH})$, $688(\mathrm{CH}), 655(\mathrm{OH}), 629(\mathrm{CH}), 594(\mathrm{CH})$. 


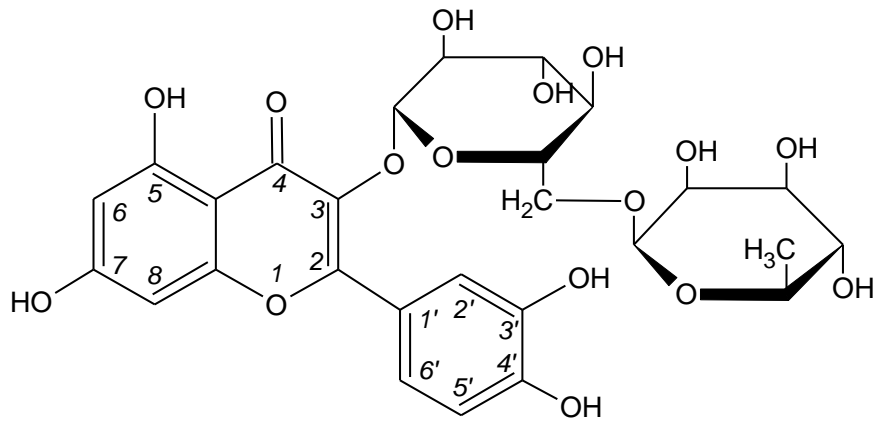

\section{Rut}

Fig. 1 Structures of Rut and GC

IR spectrum of GC $\left(v, \mathrm{~cm}^{-1}\right): 3212(\mathrm{OH}, \mathrm{NH})$, $2944(\mathrm{CH}), 2928(\mathrm{CH}), 2911(\mathrm{CH}), 2862(\mathrm{CH})$, $1726(\mathrm{C}=\mathrm{O}), 1710(\mathrm{C}=\mathrm{O}), 1692(\mathrm{C}=\mathrm{O}), 1642(\mathrm{C}(11)=\mathrm{O}$, $\mathrm{C}=\mathrm{C}), 1588\left(\mathrm{COO}^{-}\right), 1453\left(\mathrm{CH}_{2}, \mathrm{CH}_{3}\right), 1428\left(\mathrm{NH}_{4}^{+}\right)$, $1414\left(\mathrm{COO}^{-}\right), 1390(\mathrm{CH}), 1358(\mathrm{CH}), 1350(\mathrm{CH})$, $1324(\mathrm{CH}), 1304(\mathrm{CH}), 1279(\mathrm{CH}), 1258(\mathrm{CH}), 1211(\mathrm{CH})$, $1162(\mathrm{C}-\mathrm{O}-\mathrm{C}, \mathrm{C}-\mathrm{OH}), 1032(\mathrm{C}-\mathrm{O}-\mathrm{C}, \mathrm{C}-\mathrm{OH}), 980(=\mathrm{CH})$, $946(\mathrm{CH}), 918$ (monosaccharide ring), $879(\mathrm{CH})$, $868(\mathrm{CH}), 818(\mathrm{CH}), 786(\mathrm{CH}), 749(\mathrm{CH}), 692(\mathrm{CH})$, $684(\mathrm{CH}), 677(=\mathrm{CH}), 657(\mathrm{OH})$.

IR spectrum of the complex of Rut with GC $\left(\mathrm{v}, \mathrm{cm}^{-1}\right)$ : $3284(\mathrm{OH}, \mathrm{NH}), 2956(\mathrm{CH}), 2919(\mathrm{CH}), 2850(\mathrm{CH})$, $1730\left(\mathrm{C}=\mathrm{O}_{\mathrm{GC}}\right), 1715\left(\mathrm{C}=\mathrm{O}_{\mathrm{GC}}\right), 1682\left(\mathrm{C}=\mathrm{O}_{\mathrm{GC}}\right), 1639\left(\mathrm{C}=\mathrm{O}_{\mathrm{Rut}}\right)$, $1584\left(\mathrm{COO}^{-}, \mathrm{C}=\mathrm{C}_{\mathrm{Ar}}\right), 1509\left(\mathrm{C}=\mathrm{C}_{\mathrm{Ar}}\right), 1451\left(\mathrm{C}=\mathrm{C}_{\mathrm{Ar}}, \mathrm{CH}\right)$, $1424\left(\mathrm{NH}_{4}^{+}\right), 1411\left(\mathrm{COO}^{-}\right), 1360(\mathrm{C}-\mathrm{OH}, \mathrm{CH}), 1301(\mathrm{C}-\mathrm{O}-\mathrm{C}$, $\mathrm{C}-\mathrm{OH}, \mathrm{CH}), 1275$ (C-O-C, C-OH, CH), 1235 (C-O-C, C-OH), 1201 (C-O-C, C-OH), 1168 (C-O-C, C-OH), 1073 (C-O-C, $\mathrm{C}-\mathrm{OH}), 1047$ (C-O-C, C-OH), 1030 C-O-C, C-OH), $982(=\mathrm{CH}), 929(\mathrm{CH}), 878(\mathrm{CH}), 806(\mathrm{CH}), 786 \mathrm{CH})$, $717(\mathrm{CH}), 691(\mathrm{CH}), 655(\mathrm{OH}), 598(\mathrm{CH})$.

Antioxidant activity was studied on a Photochem analyzer (Analytik Jena AG, Germany). Determination of antioxidant capacity of lipid soluble compounds (ACL) and water soluble compounds (ACW) was carried out according to the manufacturer's standard protocols. ACW $=161.2 \mathrm{nM}$ and $\mathrm{ACL}=157.3 \mathrm{nM}$ (in terms of trolox for $49.5 \mathrm{mg} / \mathrm{L}$ solutions of Rut-GC complex in 70\% aqueous ethanol $(\mathrm{v} / \mathrm{v}))$.

\section{Results and discussion}

The composition of the complex of GC with Rut was determined by the isomolar series method (Figs. 2, 3). This method gave a molar ratio $\approx 1.0$ at $258 \mathrm{~nm}$, which corresponded to a 1:1 complex (Fig. 3). In addition, the isomolar curve shows a clear minimum at $361 \mathrm{~nm}$ at a 1:1 ratio of components (Fig. 3). Such ratio was obtained for complex-

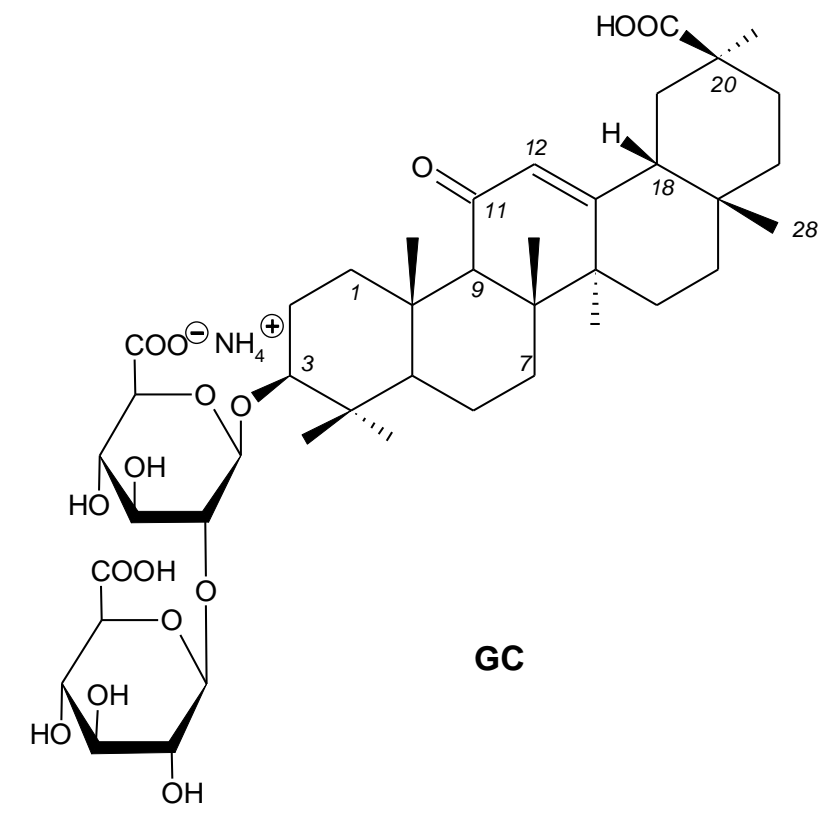

es of GA and GC with several drugs [2]. However, a different composition (1:2) was found in the complex of GC with quercetin [6]. Due to hypsochromic shift, the absorption maximum of the solutions decreases from 258 to $252 \mathrm{~nm}$ (Fig. 2).

Stability constant of the complex $\left(K_{\mathrm{GC}-\mathrm{Rut}}=(9.7 \pm \mathrm{O} .2) \cdot 1 \mathrm{O}^{4}(\mathrm{~mol} / \mathrm{L})^{-1}\right)$ was calculated based on the isomolar curves at $258 \mathrm{~nm}$ by A.K. Babko method. The previously obtained 1:1 molecular complexes of different bioactive compounds with GC had stability constants of $10^{3}-10^{5}(\mathrm{~mol} / \mathrm{L})^{-1}$ [2].

ATR FT-IR spectra of GC and Rut complex show lowfrequency shifts of the absorption band of stretching vibrations of $\mathrm{O}-\mathrm{H}$ bonds in Rut from 3415 and $3343 \mathrm{~cm}^{-1}$ to $3284 \mathrm{~cm}^{-1}$.

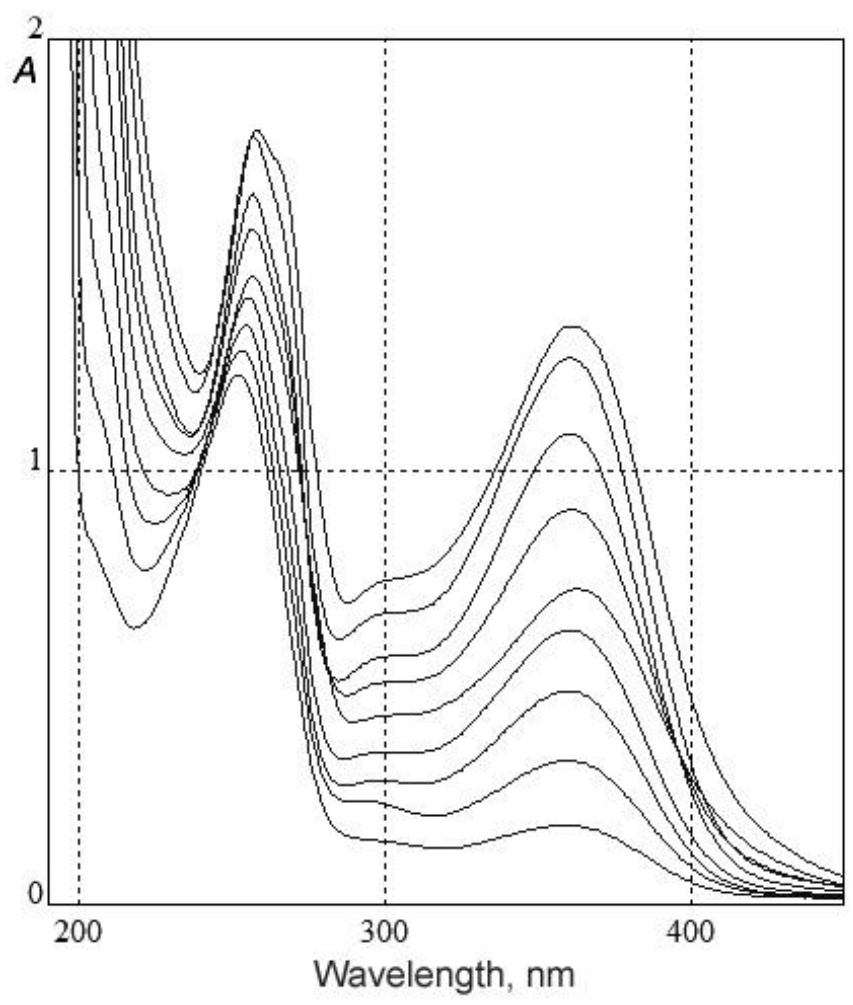

Fig. 2 Absorption curves of isomolar series of solutions at $25{ }^{\circ} \mathrm{C}$ 


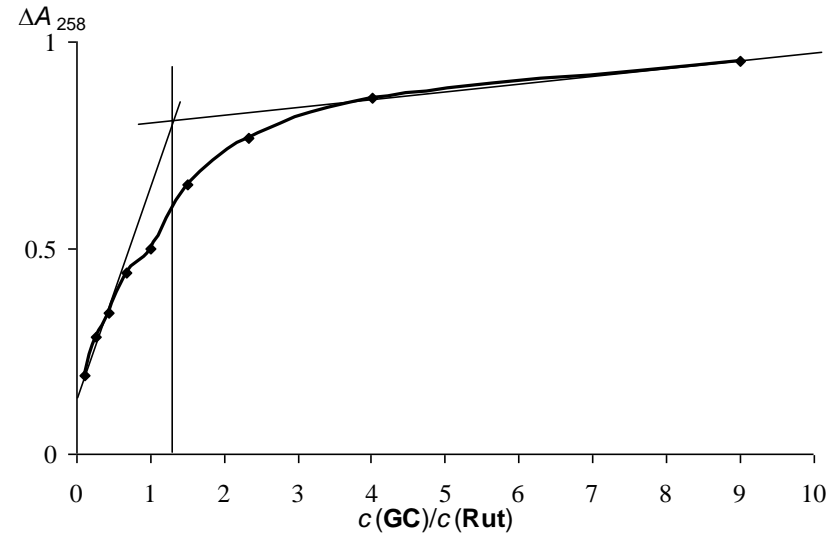

(a)

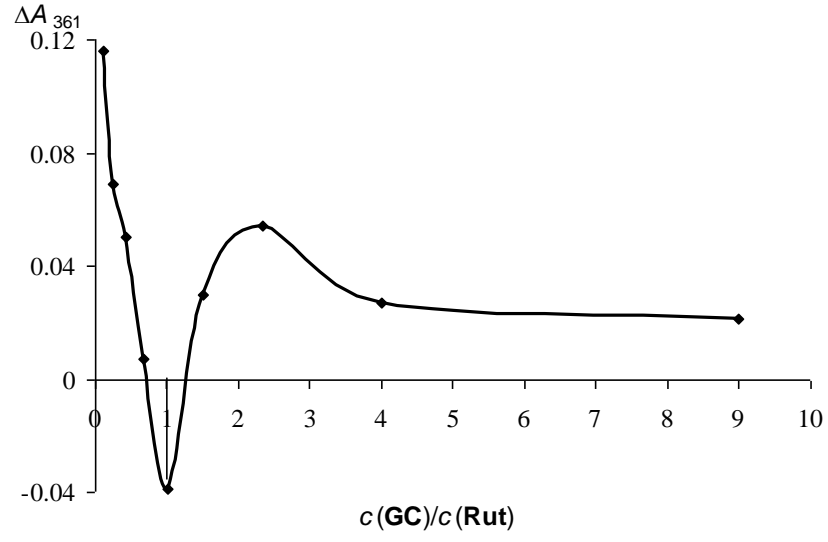

(b)

Fig. 3 Optical density change $\Delta A$ as a function of component ratio of isomolar series at $258 \mathrm{~nm}$ (a) and at $361 \mathrm{~nm}$ (b)

Such changes in the spectra confirm the formation of hydrogen bonds.

IR spectrum of complex shows certain changes related to stretching vibrations, absorption bands of $\mathrm{C}-\mathrm{O}$ bonds in $\mathrm{C}-\mathrm{O}-\mathrm{C}$ and $\mathrm{C}-\mathrm{OH}$ groups, for example $1059 \rightarrow 1047 \mathrm{~cm}^{-1}$ for Rut, $1162 \rightarrow 1168 \mathrm{~cm}^{-1}$ for GC. The presence of lowfrequency shifts of $\mathrm{C}=\mathrm{O}$ stretching vibrations, absorption band is indicative of $\mathrm{C}=\mathrm{O}$ groups of Rut and GC involvement in hydrogen bonding: $1656 \rightarrow 1639 \mathrm{~cm}^{-1}$ for Rut and $1692 \rightarrow 1682 \mathrm{~cm}^{-1}$ for GC.

In addition, the IR spectra show shifts of the main absorption bands of $\mathrm{CH}$ bonds, stretching vibrations, which can be caused by hydrophobic interactions in the complex. Their presence explains the stability of the molecular complex of GC with Rut.

Rut, GA and some complexes of GA have antioxidant activity $[1,8,9]$. For example, the antioxidant capacity of complexes of uracil derivatives with GA was studied in several oxidative systems, where they showed a higher activity than ionol [8].

A preliminary study of Rut-GC complex antioxidant activity was performed. At the same time, the analysis of the complex antioxidant capacity (in terms of trolox) showed an increase of ACW by $7.31 \%$, but a slight decrease of ACL by $2.73 \%$ in comparison with the Rut standard.

\section{Conclusions}

A joint molecular complex of triterpene and flavonoid glycosides was obtained for the first time. The composition of the complex of Rut with GC is 1:1. The complex has sufficient stability and is formed by hydrogen bonds ( $\mathrm{C}=\mathrm{O}_{\mathrm{GC}} . . . \mathrm{H}-\mathrm{O}_{\text {Rut }}$ and $\mathrm{C}=\mathrm{O}_{\text {Rut...H-OGC }}$ ) and hydrophobic contacts. Complexation of Rut with GC can improve its bioavailability and membrane permeability, and expand the spectrum of biological activity.

\section{Acknowledgements}

This study was carried out with the experimental equipment of the Sevastopol State University (project PR/80742/2017).

\section{Declaration of competing interest}

The authors declare that they have no known competing financial interests or personal relationships that could have appeared to influence the work reported in this paper.

\section{References}

1. Gullón B, Lú-Chau TA, Moreira MT, Lema JM, Eibes G. Rutin: a review on extraction, identification and purification methods, biological activities and approaches to enhance its bioavailability. Trends Food Sci Technol. 2017;67:220-35. doi:10.1016/j.tifs.2017.07.008

2. Yakovishin LA, Grishkovets VI. Ivy and licorice triterpene glycosides: promising molecular containers for some drugs and biomolecules. Stud Nat Prod Chem. 2018;55:351-83. doi:10.1016/B978-0-444-64068-0.00011-5

3. Khizrieva SS, Vetrova EV, Borisenko SN, Maksimenko EV, Borisenko NI. Synthesis and study of complexes of the novel russian antiviral drug camphecene with pentacyclic triterpenes of licorice. Chimica Techno Acta. 2020;7(4):192-98. doi:10.15826/chimtech.2020.7.4.10

4. Yakovishin LA, Grishkovets VI. Intermolecular interaction of glycyrrhizin with cholesterol. Chimica Techno Acta. 2020;7(4)180-85. doi:10.15826/chimtech.2020.7.4.08

5. Yakovishin LA. Molecular complex of glycyrrhizic acid monoammonium salt with cholesterol. Curr Bioact Compd. 2020;16(7)1042-48.

doi: $10.2174 / 1573407215666191007111603$

6. Yakovishin LA, Korzh EN. Molecular complex of quercetin with glycyram. AIP Conference Proceedings. 2019;2063:040066. doi:10.1063/5.0018047

7. Yakovishin LA, Grishkovets VI, Korzh EN, Golovchenko IV, Nagirnyak AA. Molecular complexation of hederasaponin C with cholesterol in aqueous isopropyl alcohol. Chimica Techno Acta. 2020;7(4):150-53. doi:10.15826/chimtech.2020.7.4.02

8. Myshkin VA, Srubilin DV, Enikeev DA. Antioxidant properties of pyrimidine derivatives and their molecular complexes with biologically active substances in various oxidative systems. Bashkortostan Med J. 2009;4(2):151-54. Russian.

9. Ragino YI, Vavilin VA, Salakhutdinov NF, Makarova SI, Stakhneva EM, Safronova OG, Lyakhovich VV, Nikitin YuP, Tolstikov GA. Antioxidant and endothelium-stabilizing effects of simvaglyzin on rabbits with experimental hypercholesterolemia. Bull Exp Biol Med. 2008;146(2):206-209. doi:10.1007/s10517-008-0252-X 